\title{
Research on Business English Teaching Reform in Colleges and Universities Based on Cross-border E-commerce
}

\author{
Liu Shanshan \\ Department of Foreign languages, Dongchang College of Liaocheng University, Shandong, China, \\ 252000
}

Keywords: Cross-border; e-commerce; universities; business English

\begin{abstract}
With the rapid development of cross-border e-commerce, foreign trade enterprises have a strong demand for cross-border e-commerce talents, and business English major has high practicability in this respect, which requires colleges and universities to speed up the reform of business English teaching, especially in practical teaching, and cultivate professional talents in line with market demand. From the perspective of cross-border e-commerce, this paper explores the problems existing in the practical teaching of business English in Colleges and universities and puts forward some suggestions for the reform of practical teaching.
\end{abstract}

Cross-border e-commerce is a new international trading mode in the information age. It not only needs to rely on advanced information technology and network platform, but also needs a large number of E-commerce English talents to achieve effective communication in the transaction process. However, the current e-commerce English teaching mode in our country is relatively backward, the teaching effect and quality are not ideal, and the embarrassing situation that students have strong e-commerce ability and weak English ability generally exists, which can not meet the requirements of cross-border e-commerce for e-commerce English talents, hindering the development of cross-border e-commerce in our country. The reform of e-commerce English teaching is imminent.

\section{New Requirements for E-Commerce English Teaching in the Context of Cross-Border E-Commerce}

With the rapid development of the Internet and logistics industry, a large number of related industries, especially cross-border e-commerce, have become an important way of international trade. However, the scarcity of E-commerce English talents, to a large extent, restricts the development of cross-border e-commerce. The fundamental reason for this phenomenon is that the current E-commerce English teaching model can not meet the needs of personnel training.

Cross-border e-commerce is based on e-commerce, so it requires practitioners to have a high e-commerce quality and working ability, and to be proficient in e-commerce sales platform, online payment, network security and other information-based knowledge. Moreover, cross-border 
e-commerce faces customers from all over the world. On the basis of mastering knowledge of cross-border logistics, practitioners also need to be able to communicate with customers flexibly in English. These are the new requirements of E-commerce English teaching under the background of cross-border e-commerce, and are also the ultimate goal of training E-commerce English talents.

\section{Advantages of Business English Practical Teaching Reform under the Background of Cross-border E-commerce}

With the rapid development of global economy and e-commerce industry, the cross-border trade of e-commerce has a lot of room for development. The rapid development of e-commerce enterprises at home and abroad requires a large number of business and foreign trade talents who are proficient in English, which brings good employment opportunities to business English majors in Colleges and universities.

The practical operation of cross-border e-commerce can be operated by means of Internet platform, including Express Sales, Huang Network, Amazon and so on. Therefore, university teachers can use the platform of cross-border e-commerce to train students to operate in real trade environment, so as to learn and master relevant business English and foreign trade knowledge. This is not only conducive to deepening school-enterprise cooperation, but also conducive to improving the practical operation ability of students, and making full preparations for employments.

\section{Problems in Business English Professional Training in Colleges and Universities}

\subsection{The Mode of Talent Training is Unreasonable}

In the current practice of business English teaching in Colleges and universities, too much attention has been paid to the cultivation of studentship language competence. Talents have been trained by setting up relevant English language courses and business courses. In this way, the teaching of separating business knowledge from English language training results in students not being able to fully acquire the abilities and knowledge needed by foreign trade enterprises. Secondly, the lack of a series of textbooks for business English majors in Colleges and universities will also hinder the professionalism of teaching and the cultivation of talents. Thirdly, school-enterprise cooperation can not be carried out for a long time and become mere formality, resulting in the poor quality of business English practice teaching. Business English textbooks are scarce in variety and difficult in content, which is also a major factor hindering the smooth development of project-based teaching. As shown in figure 1.

The survey results show that more than $60 \%$ of the students think that business English textbooks are not suitable for teaching. The main reason is that reading materials and listening materials are too long and difficult, which is not conducive to reading and listening comprehension. Higher vocational colleges have a rich source of students, and there are great differences in the level of students, including not only in-service college students and college graduates, but also some technical school students. The quality level of students is uneven. In addition, teachers also indicate that non-business English majors are not interested in English. 


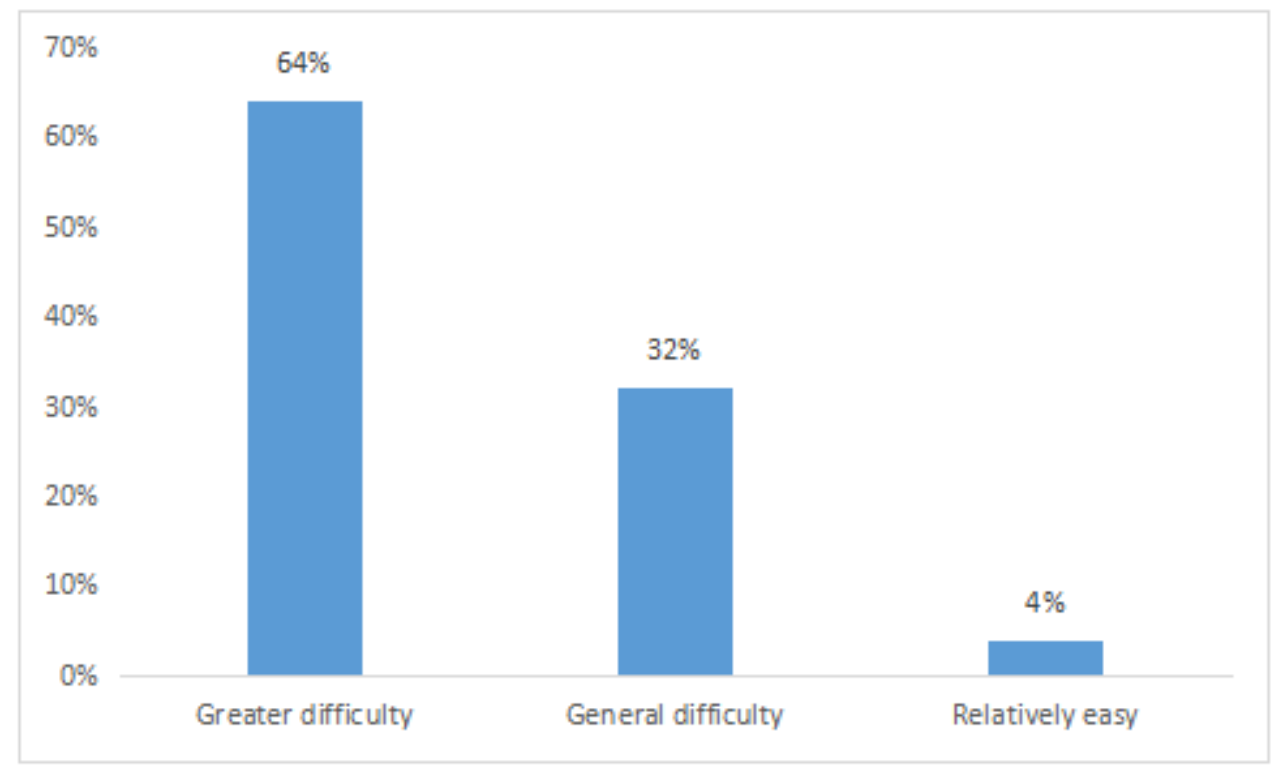

Figure 1. Assessment of the difficulty of using textbooks

\subsection{Lack of Teachers of "Double-qualified" Teachers}

An important basis for ensuring the normal and orderly development of teaching activities is the high-quality teaching staff. On the one hand, most of the teachers engaged in business English teaching in Colleges and universities graduate from English majors and have strong English language ability. However, most of these teachers also lack relevant business knowledge. Therefore, in business English teaching, especially in business English practice teaching, there is no guarantee of high quality teaching, which limits the effective learning of students in related areas.

\subsection{College Studentship-Employment Education is not Enough}

College student entrepreneurship is of great significance. Successful entrepreneurship can not only solve the problem of their own employment, but also create more jobs for the society. Especially after Prime Minister Li Kenning put forward the call of "mass entrepreneurship and innovation" in 2014, the importance of "double-creation" education has also been emphasized in the teaching practice of many colleges and universities, but the implementation is still insufficient, encouraging and actively guiding universities. It is not common for students to engage in entrepreneurial activities.

\section{E-commerce English Teaching Reform under the Background of Cross-border E-commerce}

In order to conform to the development trend of cross-border e-commerce and meet the needs of cross-border e-commerce for e-commerce English talents, it is necessary to formulate scientific and effective improvement strategies for the common problems in current e-commerce English teaching. As shown in figure 2. 

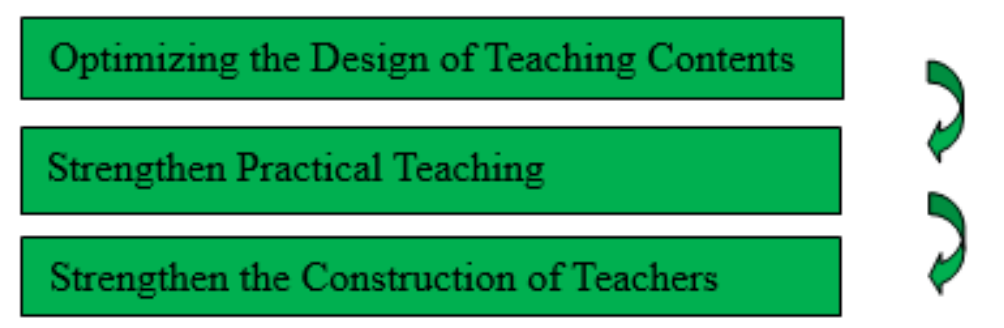

Figure 2 E-commerce English Teaching Reform under the Background of Cross-border E-commerce

\subsection{Optimizing the Design of Teaching Contents}

E-commerce English teaching content needs to meet the needs of cross-border e-commerce development, so it should be optimized. Colleges and universities should strengthen the thought of E-commerce English reform. When designing teaching content, they should orientate accurately the goal of talent cultivation, strengthen the connection between teaching content and enterprise post characteristics, and improve the professionalism of teaching content. At the same time, we should integrate the teaching contents of E-commerce, Business English and International Trade Practice so that students can master more comprehensive knowledge, help students build a perfect knowledge system, improve the comprehensive quality and ability of E-commerce English majors, and train comprehensive and applied E-commerce English talents.

\subsection{Strengthen Practical Teaching}

Practice teaching is the most important way to improve characteristically application ability. The reform of E-commerce English teaching should focus on practice teaching and strengthen practice teaching so that students can apply their knowledge flexibly in their work. Colleges and universities should clarify the importance of E-commerce English practice teaching, pay more attention to it, invest corresponding funds in the construction of practice base, improve the hardware and software infrastructure of practice teaching, create a good practice teaching environment, so that students can get full exercise. At the same time, we should strengthen cooperation with enterprises, deepen the implementation of school-enterprise cooperation, with the help of cross-border e-commerce enterprise platform accounts, to provide more hands-on opportunities for students, so that students are familiar with cross-border e-commerce business model and process in the actual operation process.

\subsection{Strengthen the Construction of Teachers}

The construction of teaching staff is the focus of E-commerce English reform. Only high-quality and high-competence teachers can play a better role in education and guidance for students. With the rapid development of cross-border e-commerce, E-commerce English teachers should establish the concept of lifelong learning, deeply understand the cross-border e-commerce market and enterprises, find out their own shortcomings and strengthen learning. At the same time, colleges and universities should regularly train E-commerce English teachers to improve their comprehensive quality and teaching ability, and do a good job in guiding students, in accordance with the current cross-border e-commerce development situation and talent training needs. In addition, we can also employ excellent business personnel as part-time teachers, who have rich practical experience and can effectively improve characteristically ability. 


\section{Conclusion}

To sum up, it is imperative to reform the practical teaching of business English in Colleges and universities. It is of great significance to reform the practical teaching of business English in the context of cross-border e-commerce. Colleges and universities should not only optimize business English teaching mode and strengthen the construction of "double-qualified" teachers, but also further deepen school-enterprise cooperation and encourage college students to start their own businesses. So as to cultivate high-quality talents for social development.

\section{Acknowledgement}

Project number: ESP course construction and teaching model research project approval number: 17CWZJ10

\section{References}

[1] Chen Fao, Ding Chongqing. An Analysis of Business English Teaching Reform and Practice in Higher Vocational Colleges Based on Cross-border E-commerce. Journal of Guiyang Vocational and Technical College, 2015 (03=) 89-94.

[2] Li Yang. Research field of curriculum reform of business English based on cross-border e-commerce. Crazy English (Teacher Edition), 2015 (02): 99-101.

[3] Au Zingy, Li Yang. Research on Foreign Language Talents Training Model under Cross-border E-commerce Tan China Business and Trade, 2014 (26): 82-83.

[4] Chaos Olivia. Reform of Business English Practice Teaching in Colleges and Universities under the Background of Cross-border E-Commerce [J]. Intelligence, 2016 (28): 140-140.

[5] Li Li. Exploration of Business English Teaching Reform under Cross-border E-Commerce Mode [J]. New West: Theory Edition, 2016 (13): 155-155. 